\title{
Elevated preoperative CEA is associated with subclinical nodal involvement and worse survival in stage I non-small cell lung cancer: a systematic review and meta- analysis
}

\author{
Awrad Nasralla ${ }^{1 *}$ (D) Jeremy Lee ${ }^{2}$, Jerry Dang ${ }^{1}$ and Simon Turner $^{3}$
}

\begin{abstract}
Background: The standard for clinical staging of lung cancer is the use of CT and PET scans, however, these may underestimate the burden of the disease. The use of serum tumor markers might aid in the detection of subclinical advanced disease. The aim of this study is to review the predictive value of tumor markers in patients with clinical stage I NSCLC.

Methods: A comprehensive search was performed using the Medline, EMBASE, Scopus data bases. Abstracts included based on the following inclusion criteria: 1) adult $\geq 18$ years old, 2) clinical stage I NSCLC, 3) Tumor markers (CEA, SCC, CYFRA 21-1), 4) further imaging or procedure, 5) > 5 patients, 6) articles in English language. The primary outcome of interest was utility of tumour markers for predicting nodal involvement and oncologic outcomes in patients with clinical stage I NSCLC. Secondary outcomes included sub-type of lung cancer, procedure performed, and follow-up duration.

Results: Two hundred seventy articles were screened, 86 studies received full-text assessment for eligibility. Of those, 12 studies were included. Total of 4666 patients were involved. All studies had used CEA, while less than 50\% used CYFRA 21-1 or SCC. The most common tumor sub-type was adenocarcinoma, and the most frequently performed procedure was lobectomy. Meta-analysis revealed that higher CEA level is associated with higher rates of lymph node involvement and higher mortality.

Conclusion: There is significant correlation between the CEA level and both nodal involvement and survival. Higher serum CEA is associated with advanced stage, and poor prognosis. Measuring preoperative CEA in patient with early stage NSCLC might help to identify patients with more advanced disease which is not detected by CT scans, and potentially identify candidates for invasive mediastinal lymph node staging, helping to select the most effective therapy for patients with potentially subclinical nodal disease. Further prospective studies are needed to standardize the use of CEA as an adjunct for NSCLC staging.
\end{abstract}

Keywords: Non-small cell lung cancer (NSCLC), carcinoembryonic antigen (CEA), lymph nodes

\footnotetext{
* Correspondence: nasralla@ualberta.ca

'Division of General Surgery, Faculty of Medicine and Dentistry, University of Alberta, Edmonton, Canada

Full list of author information is available at the end of the article
}

(c) The Author(s). 2020 Open Access This article is licensed under a Creative Commons Attribution 4.0 International License, which permits use, sharing, adaptation, distribution and reproduction in any medium or format, as long as you give appropriate credit to the original author(s) and the source, provide a link to the Creative Commons licence, and indicate if changes were made. The images or other third party material in this article are included in the article's Creative Commons licence, unless indicated otherwise in a credit line to the material. If material is not included in the article's Creative Commons licence and your intended use is not permitted by statutory regulation or exceeds the permitted use, you will need to obtain permission directly from the copyright holder. To view a copy of this licence, visit http://creativecommons.org/licenses/by/4.0/ The Creative Commons Public Domain Dedication waiver (http://creativecommons.org/publicdomain/zero/1.0/) applies to the data made available in this article, unless otherwise stated in a credit line to the data. 


\section{Introduction}

Lung cancer is the leading cause of cancer related death. Optimal treatment for non-small cell lung cancer (NSCL C) is dependent on accurate clinical staging to determine the extent of disease [1-3]. Patients with lymph node involvement have worse prognosis and may be candidates for neoadjuvant treatment prior to surgical resection. The standard for clinical staging of NSCLC is the use of computed tomography (CT) and positron emission tomography (PET) scans. However, these can underestimate the burden of the disease [4-7]. The median sensitivity and specificity of PET-CT for detection of mediastinal nodal disease is 80 and $88 \%$, respectively [8]. False negatives on imaging studies result in understaging patients who might have benefited from invasive mediastinal staging or neoadjuvant therapy $[7,9,10]$. This had led researchers to investigate the use of biomarkers to increase the sensitivity of clinical staging and allow proper treatment selection. These markers include carcinoembryonic antigen (CEA), squamous cell carcinoma antigen (SCC), and cytokeratin fragment antigen (CYFRA 21-1) $[4,11-13]$. To our knowledge this is the first systematic review about the use of tumor markers in patients with clinical stage I NSCLC for predicting lymphatic spread.

\section{Methods}

A comprehensive search was performed for articles published on non-small cell lung cancer and tumor markers using the Medline, EMBASE, Scopus data bases. Search terms included "non-small cell lung cancer" or NSCLC or lung adenocarcinoma, AND carcinoembryonic antigen or squamous cell carcinoma antigen or cytokeratin fragment antigen, AND stage I or stage IA or early stage". Literature was limited to human studies in the English language. Abstracts and titles were screened for inclusion by two reviewers (AN and JL). Non-relevant articles based on their abstract were not included for full-text evaluation. Abstracts were then further screened based on the following inclusion criteria: 1) adult patient $\geq 18$ years old, 2) primary non-small cell lung cancer (stage I or stage IA or early stage), 3) Tumor markers (Carcinoembryonic antigen (CEA), cytokeratin fragment antigen (CYFRA 21-1) and squamous cell carcinoma antigen (SCC)), 4) any further imaging such as positron

Table 1 Risk of bias assessment using NOS

\begin{tabular}{|c|c|c|c|}
\hline No. & Name of the study & Journal & Quality Score \\
\hline 1 & $\begin{array}{l}\text { Identifying Patients at Risk of Early Postoperative Recurrence of } \\
\text { Lung Cancer: A New Use of the Old CEA Test }\end{array}$ & Ann Thorac Surg & Good \\
\hline 2 & $\begin{array}{l}\text { Predictive factors for node metastasis in patients with clinical } \\
\text { stage I non-small cell lung cancer }\end{array}$ & Annals of Thoracic Surgery & Poor \\
\hline 3 & $\begin{array}{l}\text { Risk Factors for Predicting Occult Lymph Node Metastasis } \\
\text { in Patients with Clinical Stage I Non-small Cell Lung Cancer } \\
\text { Staged by Integrated Fluorodeoxyglucose Positron Emission } \\
\text { Tomography/Computed Tomography }\end{array}$ & World Journal of Surgery & Good \\
\hline 4 & $\begin{array}{l}\text { Optimal Predictive Value of Preoperative Serum Carcinoembryonic } \\
\text { Antigen for Surgical Outcomes in Stage I Non-Small Cell Lung } \\
\text { Cancer: Differences According to Histology and Smoking Status }\end{array}$ & Journal of Surgical Oncology & Fair \\
\hline 5 & $\begin{array}{l}\text { Clinical significance of preoperative carcinoembryonic antigen } \\
\text { level for clinical stage I non-small cell lung cancer: can } \\
\text { preoperative carcinoembryonic antigen level predict pathological } \\
\text { stage? }\end{array}$ & Interactive CardioVascular and Thoracic Surgery & Good \\
\hline 6 & $\begin{array}{l}\text { Predictive Risk Factors for Mediastinal Lymph Node } \\
\text { Metastasis in Clinical Stage IA Non-Small-Cell Lung Cancer } \\
\text { Patients }\end{array}$ & $\begin{array}{l}\text { Journal of Thoracic Oncology: Official Publication } \\
\text { of the International Association for the Study of } \\
\text { Lung Cancer }\end{array}$ & Fair \\
\hline 7 & $\begin{array}{l}\text { Sialyl Lewis X as a predictor of skip N2 metastasis } \\
\text { in clinical stage IA non-small cell lung cancer }\end{array}$ & World Journal of Surgical Oncology & Good \\
\hline 8 & $\begin{array}{l}\text { Clinical significance of preoperative carcinoembryonic antigen } \\
\text { level in patients with clinical stage IA non-small cell lung cancer }\end{array}$ & J Thorac Dis & Good \\
\hline 9 & $\begin{array}{l}\text { Prognostic impact of Cyfra21-1 and other serum markers in } \\
\text { completely resected non-small cell lung cancer }\end{array}$ & Lung Cancer & Good \\
\hline 10 & $\begin{array}{l}\text { Significant correlation between urinary N1, N12-diacetylspermine } \\
\text { and tumor invasiveness in patients with clinical stage IA non-small } \\
\text { cell lung cancer }\end{array}$ & BMC Cancer & Poor \\
\hline 11 & $\begin{array}{l}\text { Prediction of lymph node status in clinical stage IA } \\
\text { squamous cell carcinoma of the lung }\end{array}$ & European Journal of Cardio-Thoracic Surgery & Good \\
\hline 12 & $\begin{array}{l}\text { Predictive Factors for Lymph Node Metastasis in } \\
\text { Clinical Stage IA Lung Adenocarcinoma }\end{array}$ & Annals of Thoracic Surgery & Poor \\
\hline
\end{tabular}


emission tomography (PET) scan or procedure such as mediastinoscopy or endobronchial ultrasound (EBUS) or further treatment, 5) studies including $>5$ patients, 6) articles in English language. Exclusion criteria included non-English studies, abstracts only, and duplicates.

The primary outcome of interest was utility of tumour markers for predicting pathological tumor invasiveness in patients with clinical stage I NSCLC. Secondary outcomes included subtype of lung cancer, follow-up duration, procedure performed, smoking status, and region of publication. Meta-analysis was performed to determine the following: death within 5 years, and lymph node involvement. This study was conducted and the results are presented according to PRISMA (Preferred Reporting Items for Systematic Reviews and Meta-Analyses) guidelines.

In addition, two independent reviewers assessed the risk of bias using the Newcastle-Ottawa Scale (NOS) for evaluating the quality of the included studies. We rated the quality of the studies (good, fair and poor) according to the guidelines of the NOS. A "good" quality score required 3 or 4 points in selection, 1 or 2 points in comparability, and 2 or 3 points in outcomes. A "fair" quality score required 2 points in selection, 1 or 2 points in comparability, and 2 or 3 points in outcomes. A "poor" quality score reflected 0 or 1 point in selection, or 0

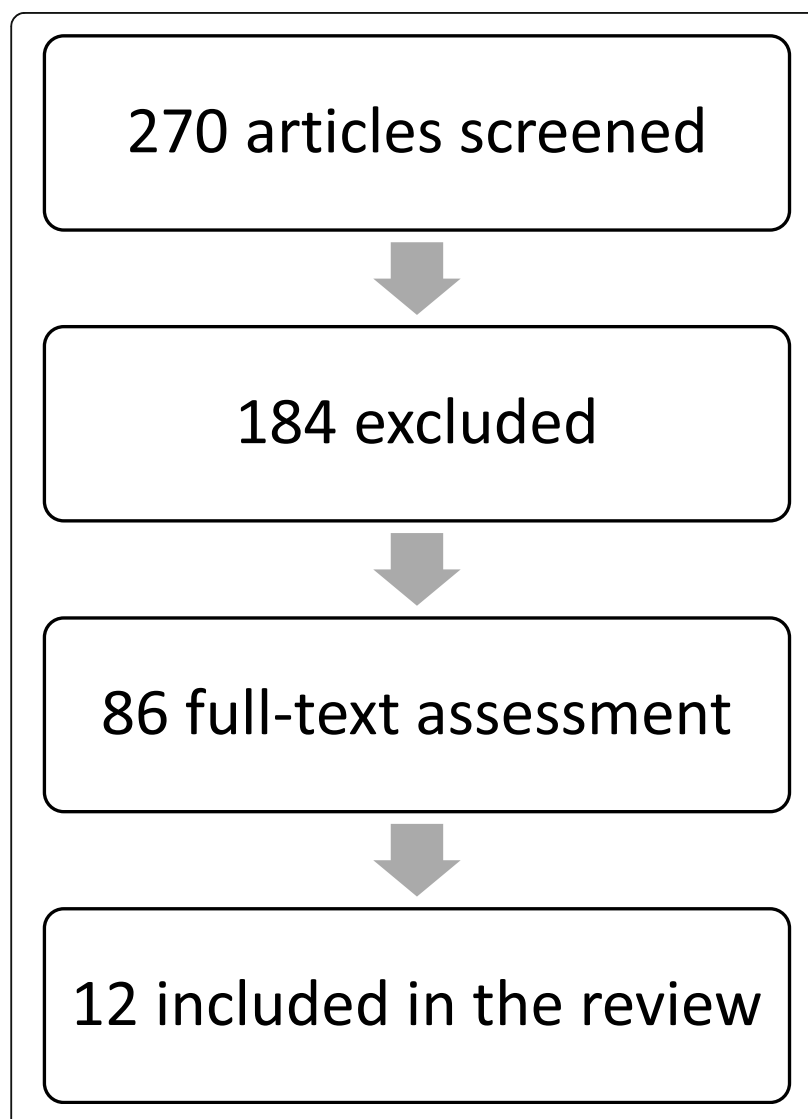

Fig. 1 PRISMA diagram with search results for systematic review points in comparability, or 0 or 1 point in outcomes (Table 1).

\section{Results}

\section{Study selection}

Preliminary literature search yielded 270 articles after duplicates were removed. All these 270 studies were screened. Eighty-six studies received full-text assessment for eligibility. Of those, 12 studies were included in the final systematic review (Fig. 1).

\section{Basic demographics}

Twelve studies with 4666 patients were included for systematic review. The majority of these studies were retrospective (10/12) and most were conducted in Japan (8/ 12). The mean age of the subjects was $65.3 \pm 3.2$ years, 2602 were males, and 2064 were females (Table 2). The mean follow-up period was 48.86 months. Nine studies, involving 3842 patients reported smoking status, in which 2003 were smokers (52.1\%).

\section{Reporting of tumor markers and tumor characteristics}

All the studies included investigated CEA, while 4 studies also used CYFRA 21-1, and 2 studies used SCC. Given there was a low number of studies looking at tumour markers other than CEA, we excluded the

Table 2 Patients demographics

\begin{tabular}{ll}
\hline Number of patients & $\mathbf{4 6 6 6}$ \\
\hline Male & 2602 \\
Female & 2064 \\
Age (mean) & $65.3 \pm 3.2$ years \\
Smoking status & \\
Smoker & 2003 \\
Non-smoker & 1839 \\
Not specified & 824 \\
Histological types & \\
Adenocarcinoma & 3622 \\
Squamous cell cancer & 697 \\
Large cell cancer & 54 \\
Adenosquamous carcinoma & 17 \\
Carcinoid tumor & 12 \\
Others & 264 \\
Follow up (mean) & 48.86 months \\
Country & \\
Japan & 8 \\
China & 1 \\
Korea & 1 \\
Germany & 1 \\
\hline Italy &
\end{tabular}




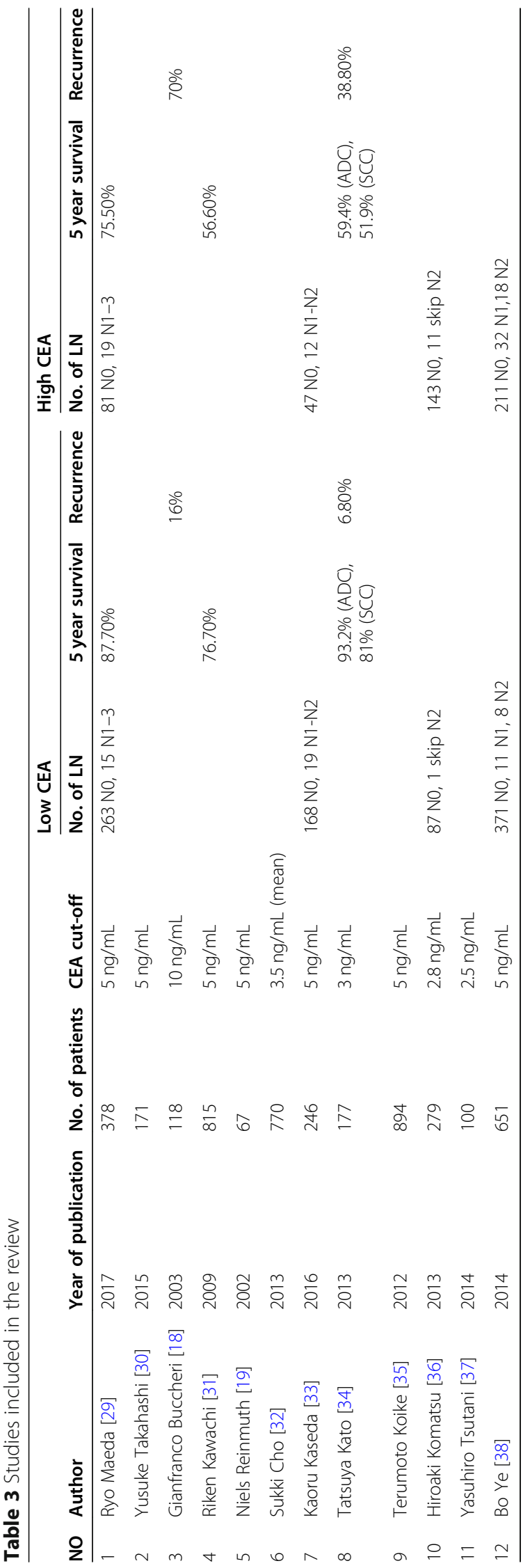




\begin{tabular}{|c|c|c|c|c|c|c|c|c|c|c|}
\hline \multirow[b]{2}{*}{ Study or Subgroup } & \multicolumn{2}{|c|}{ High CEA } & \multicolumn{2}{|c|}{ Low CEA } & \multirow[b]{2}{*}{ Weight } & \multirow{2}{*}{$\begin{array}{l}\text { Odds Ratio } \\
\text { M-H, Random, } 95 \% \mathrm{Cl}\end{array}$} & \multirow{2}{*}{\multicolumn{4}{|c|}{$\begin{array}{c}\text { Odds Ratio } \\
\text { M-H, Random, } 95 \% \mathrm{Cl}\end{array}$}} \\
\hline & Events & Total & Events & Total & & & & & & \\
\hline Kato 2013 & 27 & 67 & 5 & 74 & $20.2 \%$ & $9.31[3.32,26.11]$ & & & $\longrightarrow$ & \\
\hline Kawachi 2009 & 119 & 274 & 126 & 541 & $45.3 \%$ & $2.53[1.85,3.45]$ & & & & \\
\hline Maeda 2017 & 24 & 100 & 34 & 278 & $34.5 \%$ & $2.27[1.27,4.06]$ & & & $\longrightarrow$ & \\
\hline Total $(95 \% \mathrm{Cl})$ & & 441 & & 893 & $100.0 \%$ & $3.17[1.75,5.73]$ & & & & \\
\hline Total events & 170 & & 165 & & & & & & & \\
\hline $\begin{array}{l}\text { Heterogeneity: } \mathrm{Tau}^{2}= \\
\text { Test for overall effect: }\end{array}$ & $\begin{array}{l}0.18 ; \mathrm{Chi}^{2} \\
\mathrm{Z}=3.81(\mathrm{P}\end{array}$ & $\begin{array}{l}=6.11 \\
P=0.0\end{array}$ & $\begin{array}{l}\mathrm{df}=2(\mathrm{P} \\
001)\end{array}$ & $=0.05$ & $; I^{2}=67 \%$ & & 0.01 & $\begin{array}{cc}0.1 & 1 \\
\text { Favours High CEA }\end{array}$ & $\begin{array}{c}10 \\
\text { Favours Low CEA }\end{array}$ & 100 \\
\hline
\end{tabular}

analysis of these markers from our review. The cut-off value for abnormal CEA differed among the studies, ranging from 2.5 to $10 \mathrm{ng} / \mathrm{mL}$ (Table 3). Seven out of the twelve articles included in this review had used $5 \mathrm{ng} / \mathrm{mL}$ as cut-off value. The majority of the studies involved the use of PET scan (10 studies) for clinical staging, while fewer studies used EBUS (2 studies), mediastinoscopy (1 study), or image guided biopsy (1 study). The most frequently performed procedure was lobectomy (2715, $67.7 \%)$, followed by segmentectomy $(374,11.8 \%)$, wedge resection $(47,1.5 \%)$, pneumonectomy $(45,1.4 \%)$,bilobecomy $(24,7.6 \%)$. However, 4 studies did not specify the operative procedure. The tumor sub-types were: adenocarcinoma (3622, 77.6\%), squamous cell cancer (697, $14.9 \%)$, large cell cancer (54, 1.2\%), adenosquamous (17, $0.4 \%)$, carcinoid $(12,0.3 \%)$, other $(264,5.7 \%)$ (Table 3$)$. Postoperative staging were specified in 7 studies as the following: stage I $(1,228,79.2 \%)$, stage II $(121,7.8 \%)$, stage III $(198,12.8 \%)$, stage IV $(3,0.2 \%)$. Pathologic lymph node status were: NO $(2315,86.3 \%)$, N1 (192, 6.7\%), N2 (158), N 1-3 (197, 5.5\%), while three studies did not report lymph nodes details. Meta-analysis was performed to determine the association of high CEA with death within 5 years and lymph node involvement. High CEA had an odds of death within 5 years that is 3.17 times that of low CEA (95\% CI 1.75 to 5.73, $p=$ $0.0001)$. This result had high heterogeneity (chi $2=67 \%$, $p=0.05)$. This analysis included 3 studies and 1334 patients (Fig. 2). For nodal status, high CEA had a higher odds of there being any positive nodal metastases (OR $3.85,95 \%$ CI 2.64 to $5.62, p<0.00001$ ) compared to low CEA. This result had low heterogeneity (chi2 $=0 \%, p=$ 0.48). This analysis included 4 studies and 1517 patients (Fig. 3). Further subanalysis revealed that high CEA had higher odds of positive N2 that is 3.61 times that of low CEA (95\% CI 1.73 to $7.53, p=0.0006$ ). This analysis included 2 studies and 1085 patients (Fig. 4). Heterogeneity was low (chi2 $=0 \%, p=0.53$ ).

\section{Risk of bias assessment}

Most of the studies included had good or fair quality score, only 3 studies their quality score was poor. Those whose scored poor on their quality lost some point on follow up.

\section{Discussion}

Accurate preoperative staging of NSCLC is integral for appropriate treatment plan. The main treatment for patients with stage I NSCLC is surgery. Unfortunately, due to limited sensitivity of preoperative imaging, up to $30 \%$ of patients with stage I NSCLC may have positive N2$\mathrm{N} 3$ lymph nodes at the time of resection $[8,14,15]$. A meta-analysis of 20 studies showed that mediastinal lymph node staging using CT scan had $57 \%$ sensitivity and $82 \%$ specificity [16]. Similarly, Cerfolio et al. showed that 7 of 17 patients with $\mathrm{cN} 1$ (41\%) were found to have positive $\mathrm{N} 2$ after lymph node sampling by mediastinoscopy or endoscopic ultrasound with fine needle

\begin{tabular}{|c|c|c|c|c|c|c|c|c|c|c|}
\hline Study or Subgroup & \multicolumn{2}{|c|}{ High CEA } & \multicolumn{2}{|c|}{ Low CEA } & Weight & $\begin{array}{c}\text { Odds Ratio } \\
\text { M-H, Random, } 95 \% \mathrm{Cl}\end{array}$ & \multicolumn{4}{|c|}{$\begin{array}{c}\text { Odds Ratio } \\
\text { M-H, Random, } 95 \% \mathrm{Cl}\end{array}$} \\
\hline Kaseda 2016 & 12 & 59 & 19 & 187 & $22.8 \%$ & $2.26[1.02,4.98]$ & & & $\square$ & \\
\hline Komatsu 2013 & 11 & 154 & 1 & 88 & $3.4 \%$ & $6.69[0.85,52.74]$ & & & & \\
\hline Maeda 2017 & 19 & 100 & 15 & 278 & $27.4 \%$ & $4.11[2.00,8.46]$ & & & $\longrightarrow$ & \\
\hline Ye 2014 & 50 & 261 & 19 & 390 & $46.4 \%$ & $4.63[2.66,8.06]$ & & & - & \\
\hline Total $(95 \% \mathrm{Cl})$ & & 574 & & 943 & $100.0 \%$ & $3.85[2.64,5.62]$ & & & & \\
\hline Total events & 92 & & 54 & & & & & & & \\
\hline $\begin{array}{l}\text { Heterogeneity: } \mathrm{Tau}^{2}= \\
\text { Test for overall effect: }\end{array}$ & $\begin{array}{l}0.00 ; \mathrm{Chi}^{2} \\
z=6.99(\mathrm{~F}\end{array}$ & $\begin{array}{l}=2.50 \\
P<0.0\end{array}$ & $\begin{array}{l}, \mathrm{df}=3(\mathrm{P} \\
0001)\end{array}$ & $=0.48)$ & $; 1^{2}=0 \%$ & & 0.01 & $\begin{array}{c}0.1 \\
\text { Favours High CEA }\end{array}$ & $\begin{array}{c}10 \\
\text { Favours Low CEA }\end{array}$ & 100 \\
\hline
\end{tabular}




\begin{tabular}{|c|c|c|c|c|c|c|c|c|c|c|}
\hline \multirow{4}{*}{$\begin{array}{l}\text { Study or Subgroup } \\
\text { Komatsu } 2013 \\
\text { Ye } 2014\end{array}$} & \multicolumn{2}{|c|}{ Experimental } & \multicolumn{2}{|c|}{ Control } & \multirow[b]{2}{*}{ Weight } & \multirow{2}{*}{$\begin{array}{c}\text { Odds Ratio } \\
\text { M-H, Random, } 95 \% \mathrm{Cl}\end{array}$} & \multirow{2}{*}{\multicolumn{4}{|c|}{$\begin{array}{c}\text { Odds Ratio } \\
\text { M-H, Random, } 95 \% \mathrm{Cl} \\
\end{array}$}} \\
\hline & Events & Total & Events & Total & & & & & & \\
\hline & 11 & 154 & 1 & 88 & $12.7 \%$ & $6.69[0.85,52.74]$ & & & & \\
\hline & 32 & 472 & 8 & 371 & $87.3 \%$ & $3.30[1.50,7.25]$ & & & & \\
\hline Total $(95 \% \mathrm{Cl})$ & & 626 & & 459 & $100.0 \%$ & $3.61[1.73,7.53]$ & & & & \\
\hline Total events & 43 & & 9 & & & & & & & \\
\hline $\begin{array}{l}\text { Heterogeneity: } \mathrm{Tau}^{2}= \\
\text { Test for overall effect: }\end{array}$ & $\begin{array}{l}.00 ; \mathrm{Chi}^{2} \\
=3.42(\mathrm{P}\end{array}$ & $\begin{array}{r}0.40, d \\
=0.000\end{array}$ & $\begin{array}{l}\text { If }=1(P= \\
6)\end{array}$ & $=0.53)$ & $I^{2}=0 \%$ & & 0.01 & $\begin{array}{cc}0.1 & 1 \\
\text { Favours High CEA } & \end{array}$ & $\begin{array}{c}10 \\
\text { Favours Low CEA }\end{array}$ & 100 \\
\hline
\end{tabular}

aspiration (EUS FNA), although N2 involvement was excluded initially by PET/CT scan [17]. The ability to detect subclinical nodal involvement prior to surgery could allow identification of cN0 patients who might benefit from invasive staging, while patients with low CEA levels could conceivably be spared invasive staging if they would otherwise qualify for reasons such as large tumour size or central tumour. Better preoperative staging should result in improved treatment selection, as patients may benefit from neoadjuvant chemotherapy or chemoradiotherapy rather than upfront surgery. In patients with early stage I NSCLC, in whom lymph sampling versus lymph dissection is controversial, the use of CEA could also identify patients in need of more aggressive lymphadenectomy [18-20]. Whether the increased risk of mortality found in this meta-analysis is completely attributable to the increased rate of nodal involvement can not be determined from the available studies' data, but identification of patients with poor prognosis related to high CEA may also allow for a more tailored approach to post-resection surveillance and patient counselling.

Due to the limited ability of preoperative imaging CT or PET-CT to detect mediastinal lymph nodes disease, interest in serum biomarkers in lung cancer is growing. The most frequently studied tumor marker is carcinoembryonic antigen. All histological types of lung cancer can produce CEA and a role for its use in lung cancer screening and staging was first proposed in the 1970s [21-25]. Recently, studies have demonstrated the usefulness of CEA in patients with NSCLC for postoperative follow up, response to chemotherapy, recurrence, and prognosis. High CEA level has been correlated with advanced disease and poor prognosis. Serum CEA measurement is a simple, non-invasive, inexpensive test. In such case, patients with high CEA level might benefit from lymph node sampling by mediastinoscopy or endoscopic ultrasound with fine needle aspiration (EUS FNA) [18, 25-27]. As shown in our meta-analysis CEA level is correlated with lymph node involvement, and further sub-analysis did reveal that higher CEA associated with positive N2.

There is a discrepancy in the cut-off value of CEA ranges from 2.5 to $10 \mathrm{ng} / \mathrm{mL}$ and is attributable to the different techniques used for measurement such as radioimmunoassay (RIA) and enzyme immunoassay [21, 28]. Further studies are needed to standardize the cutoff value. Our meta-analysis about lymph nodes involvement and death within 5 years was limited to few studies because most did not mention the specific details needed to conduct the analysis. Other limitations in our study include the following: the majority of included studies were retrospective, done in a single country (Japan) and many lacked specific lymph nodes details (N0, N1, N2, N3). In addition, we excluded non-English articles. As such we recommend a prospective study using CEA preoperatively to accurately correlate the level of CEA with risk of lymph nodes metastasis, and to determine the cut-off value of CEA.

\section{Conclusion}

There is significant correlation between the CEA level and both nodal involvement and survival. Higher level of CEA is associated with advanced stage, and poor prognosis. Performing preoperative CEA in patient with early stage NSCLC might help to identify patients with more advanced disease which is not detected by imaging, and potentially identify patients for invasive mediastinal lymph node staging, helping to select the most effective therapy for patients with potentially subclinical nodal disease. Further prospective studies are needed to standardize the use of CEA as an adjunct for NSCLC staging.

\section{Abbreviations \\ EBUS: Endobronchial ultrasound; CT: Computed tomography; PET: Positron emission tomography; LN or N: Lymph node; CN: clinical stage lymph node; NSCLC: Non-small cell lung cancer; CEA: Carcinoembryonic antigen; SCC: Squamous cell carcinoma antigen; CYFRA 21-1: Cytokeratin fragment antigen; EUS FNA: Endoscopic ultrasound with fine needle aspiration; RIA: Radioimmunoassay; NOS: Newcastle-Ottawa Scale}

\section{Acknowledgements}

University of Alberta librarian who provided teaching how to conduct a comprehensive search.

\section{Authors' contributions}

Awrad Nasralla: comprehensive search, data screening, data collection, data analysis, and writing the paper. Jeremy Lee: data screening, collection and analysis. Jerry Dang: meta-analysis. Simon Turner: supervision, data analysis, and writing the paper. The author(s) read and approved the final manuscript. 


\section{Funding}

None.

\section{Availability of data and materials}

Possible upon request, we can share our Excel sheet of data.

\section{Ethics approval and consent to participate}

Informed consent does not apply for this type of study.

\section{Consent for publication}

Not applicable.

\section{Competing interests}

None.

\section{Author details}

'Division of General Surgery, Faculty of Medicine and Dentistry, University of Alberta, Edmonton, Canada. ${ }^{2}$ Faculty of Medicine and Dentistry, University of Alberta, Edmonton, Canada. ${ }^{3}$ Division of Thoracic Surgery, Faculty of Medicine and Dentistry, University of Alberta, Edmonton, Canada.

\section{Received: 5 June 2020 Accepted: 28 September 2020}

\section{Published online: 15 October 2020}

\section{References}

1. Barta JA, Powell CA, Wisnivesky JP, Glob A, Author H. Global Epidemiology of Lung Cancer HHS Public Access Author manuscript. Ann Glob Heal. 2019; 85(1) [cited 2020 Feb 25]. Available from: http://creativecommons.org/ licenses/by/4.0/.

2. Zhang C, Leighl NB, Wu Y-L, Zhong W-Z. Emerging therapies for non-small cell lung cancer. J Hematol Oncol. 2019;12(1):45 [cited 2020 Feb 25]. Available from: https://jhoonline.biomedcentral.com/articles/10.1186/s13045019-0731-8.

3. Andersson S, Ilonen I, Järvinen T, Rauma V, Räsänen J, Salo J. Surgically Treated Unsuspected N2-Positive NSCLC: Role of Extent and Location of Lymph Node Metastasis. Clin Lung Cancer. 2018;19(5):418-25 [cited 2020 may 30]. Available from: http://www.ncbi.nlm.nih.gov/pubmed/29880414.

4. Chen F, Wang X-Y, Han X-H, Wang H, Qi J. Diagnostic value of Cyfra21-1, SCC and CEA for differentiation of early-stage NSCLC from benign lung disease. Int J Clin Exp Med. 2015;8(7):11295-300 [cited 2020 Feb 25]. Available from: http://www.ncbi.nlm.nih.gov/pubmed/26379938.

5. McDonald F, De Waele M, Hendriks LEL, Faivre-Finn C, Dingemans A-MC, Van Schil PE. Management of stage I and II nonsmall cell lung cancer. Eur Respir J. 2017:49(1) [cited 2020 Feb 25]. Available from: http://www.ncbi. nlm.nih.gov/pubmed/28049169.

6. Aktas GE, Karamustafaoğlu YA, Balta C, Süt N, Sarikaya I, Sarikaya A Prognostic significance of fluorine-18 fluorodeoxyglucose positron emission tomography/computed tomography-derived metabolic parameters in surgically resected clinical-NO nonsmall cell lung cancer. Nucl Med Commun. 2018;39(11):995-1004 [cited 2020 Feb 28]. Available from: http://www.ncbi.nlm.nih.gov/pubmed/30188416.

7. Gómez-Caro A, Garcia S, Reguart N, Arguis P, Sanchez M, Gimferrer JM, et al. Incidence of occult mediastinal node involvement in $\mathrm{cNO}$ non-small-cell lung cancer patients after negative uptake of positron emission tomography/computer tomography scan. Eur J Cardiothorac Surg. 2010; 37(5):1168-1174 [cited 2020 May 30]. Available from: http://www.ncbi.nlm. nih.gov/pubmed/20116273

8. D'Andrilli A, Maurizi G, Venuta F, Rendina EA. Mediastinal staging: when and how? Gen Thorac Cardiovasc Surg. 2020:68(7):725-32. https://doi.org/10. 1007/s11748-019-01263-8.

9. Turner SR, Seyednejad N, Nasir BS. Patterns of Practice in Mediastinal Lymph Node Staging for Non-Small Cell Lung Cancer in Canada. Ann Thorac Surg. 2018:106(2):428-34 [cited 2020 Feb 25]. Available from: http://www.ncbi. nlm.nih.gov/pubmed/29596820.

10. Cho HJ, Kim SR, Kim HR, Han J-O, Kim Y-H, Kim DK, et al. Modern outcome and risk analysis of surgically resected occult N2 non-small cell lung cancer. Ann Thorac Surg. 2014;97(6):1920-5 [cited 2020 may 30]. Available from: http://www.ncbi.nlm.nih.gov/pubmed/24768044.

11. Yang-Chun F, Min F, Di Z, Yan-Chun H. Retrospective Study to Determine Diagnostic Utility of 6 Commonly Used Lung Cancer Biomarkers Among Han and Uygur Population in Xinjiang Uygur Autonomous Region of People's
Republic of China. Medicine (Baltimore). 2016;95(18):e3568 [cited 2020 may 30] Available from: http://www.ncbi.nlm.nih.gov/pubmed/27149479.

12. Yu H, Huang $X, Z$ hu Z, Hu Y, Ou W, Zhang $L$, et al. Significance of combined detection of LunX mRNA and tumor markers in diagnosis of lung carcinoma. Chin J Cancer Res [Internet]. 2014;26(1):89-94 [cited 2020 may 30]. Available from: http://www.ncbi.nlm.nih.gov/pubmed/24653630.

13. Molina R, Marrades RM, Augé JM, Escudero JM, Viñolas N, Reguart N, Ramirez J, Filella X, Molins L, Agustí A. Assessment of a combined panel of six Serum tumor markers for Lung Cancer. Am J Respir Crit Care Med. 2016; 193(4):427-37. https://doi.org/10.1164/rccm.201404-06030C.

14. Decaluwé H, Dooms C, D'Journo XB, Call S, Sanchez D, Haager B, et al. Mediastinal staging by videomediastinoscopy in clinical N1 non-small cell lung cancer: a prospective multicentre study. Eur Respir J. 2017;50(6) [cited 2020 may 30]. Available from: http://www.ncbi.nlm.nih.gov/pubmed/29269579.

15. Hishida T, Yoshida J, Nishimura M, Nishiwaki Y, Nagai K. Problems in the current diagnostic standards of clinical N1 non-small cell lung cancer. Thorax. 2008;63(6):526-31 [cited 2020 may 30]. Available from: http://www. ncbi.nlm.nih.gov/pubmed/18024539.

16. Toloza EM, Harpole L, DC MC. Noninvasive staging of non-small cell lung cancer: a review of the current evidence. Chest. 2003;123(1 Suppl):137S-46S [cited 2020 may 30]. Available from: http://www.ncbi.nlm.nih.gov/ pubmed/12527573.

17. Cerfolio RJ, Bryant AS, Eloubeidi MA. Routine mediastinoscopy and esophageal ultrasound fine-needle aspiration in patients with non-small cell lung cancer who are clinically N2 negative: a prospective study. Chest. 2006; 130(6):1791-5 [cited 2020 May 30]. Available from: http://www.ncbi.nlm.nih. gov/pubmed/17166998.

18. Buccheri $G$, Ferrigno D. Identifying patients at risk of early postoperative recurrence of lung cancer: a new use of the old CEA test. Ann Thorac Surg. 2003;75(3):973-80 [cited 2020 Feb 28]. Available from: https://inkinghub. elsevier.com/retrieve/pii/S0003497502046386.

19. Reinmuth $N$, Brandt B, Semik M, Kunze W-P, Achatzy R, Scheld HH, et al. Prognostic impact of Cyfra21-1 and other serum markers in completely resected non-small cell lung cancer. Lung Cancer. 2002;36(3):265-70 [cited 2020 Feb 28]. Available from: http://www.ncbi.nlm.nih.gov/pubmed/12 009236.

20. Suzuki K, Nagai K, Yoshida J, Moriyama E, Nishimura M, Takahashi K, et al. Prognostic factors in clinical stage I non-small cell lung cancer. Ann Thorac Surg [Internet]. 1999;67(4):927-932 [cited 2020 Feb 28]. Available from: http://www.ncbi.nlm.nih.gov/pubmed/10320230.

21. Hanagiri T, Sugaya M, Takenaka M, Oka S, Baba T, Shigematsu Y, et al. Preoperative CYFRA 21-1 and CEA as prognostic factors in patients with stage I non-small cell lung cancer. Lung Cancer. 2011;74(1):112-7 [cited 2020 May 30]. Available from: http://www.ncbi.n/m.nih.gov/pubmed/213 97974.

22. Hsu W-H, Huang C-S, Hsu H-S, Huang W-J, Lee H-C, Huang B-S, et al. Preoperative serum carcinoembryonic antigen level is a prognostic factor in women with early non-small-cell lung cancer. Ann Thorac Surg. 2007:83(2): 419-24 [cited 2020 may 30]. Available from: http://www.ncbi.nlm.nih.gov/ pubmed/17257963.

23. Concannon JP, Dalbow MH, Hodgson SE, Headings JJ, Markopoulos E, Mitchell J, et al. Prognostic value of preoperative carcinoembryonic antigen (CEA) plasma levels in patients with bronchogenic carcinoma. Cancer. 1978; 42(S3):1477-83 [cited 2020 May 30]. Available from: https://acsjournals. onlinelibrary.wiley.com/doi/abs/10.1002/10970142(197809)42:3+\%3C1477:: AID-CNCR2820420818\%3E3.0.CO;2-E.

24. Schmidt-Hansen M, Baldwin DR, Hasler E, Zamora J, Abraira V, Roqué I, Figuls M. PET-CT for assessing mediastinal lymph node involvement in patients with suspected resectable non-small cell lung cancer. Cochrane Datab Syst Rev. 2014;2014(11):CD009519 [cited 2020 may 30]. Available from: http://www.ncbi.nlm.nih.gov/pubmed/25393718.

25. Kuo $Y-S$, Zheng M-Y, Huang M-F, Miao C-C, Yang L-H, Huang T-W, et al. Association of Divergent Carcinoembryonic Antigen Patterns and Lung Cancer Progression. Sci Rep [Internet]. 2020;10(1):2066 [cited 2020 May 30]. Available from: http://www.ncbi.nlm.nih.gov/pubmed/32034239.

26. Sawabata N, Ohta M, Takeda S, Hirano H, Okumura Y, Asada H, et al. Serum carcinoembryonic antigen level in surgically resected clinical stage I patients with non- small cell lung cancer. Ann Thorac Surg. 2002;74(1):174-9 [cited 2020 may 30]. Available from: http://www.ncbi.nlm.nih.gov/pubmed/12118753.

27. Wang J, Ma Y, Zhu Z-H, Situ D-R, Hu Y, Rong T-H. Expression and prognostic relevance of tumor carcinoembryonic antigen in stage IB non-small cell 
lung cancer. J Thorac Dis. 2012;4(5):490-6 [cited 2020 may 30]. Available from: http://www.ncbi.nlm.nih.gov/pubmed/23050113.

28. Nisselbaum JS, Smith CA, Schwartz D, Schwartz MK. Comparison of Roche RIA, Roche EIA, Hybritech EIA, and Abbott EIA methods for measuring carcinoembryonic antigen. ClinChem. 1988;34(4):761-4 Available from: https://doi.org/10.1093/clinchem/34.4.761.

29. Maeda R, Suda T, Hachimaru A, Tochii D, Tochii S, Takagi Y. Clinical significance of preoperative carcinoembryonic antigen level in patients with clinical stage IA non-small cell lung cancer. J Thorac Dis. 2017;9(1):176-86. https://doi.org/10.21037/jtd.2017.01.30.

30. Takahashi Y, Horio H, Sakaguchi K, Hiramatsu K, Kawakita M. Significant correlation between urinary N1, N12-diacetylspermine and tumor invasiveness in patients with clinical stage IA non-small cell lung cancer. BMC Cancer. 2015;15(1):65 [cited 2020 Feb 28]. Available from: http:// bmccancer.biomedcentral.com/articles/10.1186/s12885-015-1068-5.

31. Kawachi R, Nakazato Y, Takei H, Koshi-ishi Y, Goya T. Clinical significance of preoperative carcinoembryonic antigen level for clinical stage I non-small cell lung cancer: can preoperative carcinoembryonic antigen level predict pathological stage? Interact Cardiovasc Thorac Surg. 2009;9(2):199-202 [cited 2020 Feb 28]. Available from: http://www.ncbin.nlm.nih.gov/pubmed/1 9457896.

32. Cho S, Song IH, Yang HC, Kim K, Jheon S. Predictive Factors for Node Metastasis in Patients With Clinical Stage I Non-Small Cell Lung Cancer. Ann Thorac Surg. 2013;96(1):239-45 [cited 2020 Feb 28]. Available from: https:// linkinghub.elsevier.com/retrieve/pii/S0003497513006309.

33. Kaseda K, Asakura K, Kazama A, Ozawa Y. Risk Factors for Predicting Occult Lymph Node Metastasis in Patients with Clinical Stage I Non-small Cell Lung Cancer Staged by Integrated Fluorodeoxyglucose Positron Emission Tomography/Computed Tomography. World J Surg. 2016;40(12):2976-83 [cited 2020 Feb 28]. Available from: http://www.ncbinlm.nih.gov/pubmed/2 7456499.

34. Kato T, Ishikawa K, Aragaki M, Sato M, Okamoto K, Ishibashi T, et al. Optimal predictive value of preoperative serum carcinoembryonic antigen for surgical outcomes in stage I non-small cell lung cancer: Differences according to histology and smoking status. J Surg Oncol. 2013;107(6):61924 [cited 2020 Feb 28]. Available from: http://www.ncbi.nlm.nih.gov/ pubmed/23192365.

35. Koike T, Koike T, Yamato Y, Yoshiya K, Toyabe S-I. Predictive risk factors for mediastinal lymph node metastasis in clinical stage IA non-small-cell lung cancer patients. J Thorac Oncol. 2012;7(8):1246-51 [cited 2020 Feb 25] Available from: http://www.ncbi.nlm.nih.gov/pubmed/22659962.

36. Komatsu H, Mizuguchi S, Izumi N, Chung K, Hanada S, Inoue H, et al. Sialyl Lewis $\mathrm{X}$ as a predictor of skip N2 metastasis in clinical stage IA non-small cell lung cancer. World I SurgOncol. 2013;11:309 [cited 2020 Feb 28]. Available from: http://www.ncbi.nlm.nih.gov/pubmed/24313932.

37. Tsutani Y, Murakami S, Miyata Y, Nakayama H, Yoshimura M, Okada M. Prediction of lymph node status in clinical stage IA squamous cell carcinoma of the lung. Eur J Cardio-Thoracic Surg. 2015;47(6):1022-6 [cited 2020 Feb 28]. Available from: http://www.ncbi.nlm.nih.gov/pubmed/25293403.

38. Ye B, Cheng M, Li W, Ge X-X, Geng J-F, Feng J, et al. Predictive factors for lymph node metastasis in clinical stage IA lung adenocarcinoma. Ann Thorac Surg. 2014;98(1):217-23 [cited 2020 Feb 28]. Available from: http://www.ncbi.nlm.nih.gov/pubmed/24841547.

\section{Publisher's Note}

Springer Nature remains neutral with regard to jurisdictional claims in published maps and institutional affiliations.

Ready to submit your research? Choose BMC and benefit from:
- fast, convenient online submission
- thorough peer review by experienced researchers in your field
- rapid publication on acceptance
- support for research data, including large and complex data types
- gold Open Access which fosters wider collaboration and increased citations
- maximum visibility for your research: over 100M website views per year
At BMC, research is always in progress.
Learn more biomedcentral.com/submissions

